\title{
Current Advances in the Biochemical and Physiological Aspects of the Treatment of Type 2 Diabetes Mellitus with Thiazolidinediones
}

\author{
D. Alemán-González-Duhart, ${ }^{1}$ F. Tamay-Cach, ${ }^{2}$ \\ S. Álvarez-Almazán, ${ }^{1}$ and J. E. Mendieta-Wejebe ${ }^{1}$ \\ ${ }^{1}$ Laboratorio de Biofísica y Biocatálisis, Sección de Estudios de Posgrado e Investigación, Escuela Superior de Medicina, \\ Instituto Politécnico Nacional, Plan de San Luis y Salvador Díaz Mirón, Casco de Santo Tomás, 11340 Ciudad de México, DF, Mexico \\ ${ }^{2}$ Laboratorio de Investigación en Bioquímica, Departamento de Formación Básica Disciplinaria y Sección de Estudios \\ de Posgrado e Investigación, Escuela Superior de Medicina, Instituto Politécnico Nacional, Plan de San Luis y Salvador Díaz Mirón, \\ Casco de Santo Tomás, 11340 Ciudad de México, DF, Mexico
}

Correspondence should be addressed to J. E. Mendieta-Wejebe; jesmenwej@yahoo.com

Received 18 March 2016; Accepted 24 April 2016

Academic Editor: Yue Zhang

Copyright ( 2016 D. Alemán-González-Duhart et al. This is an open access article distributed under the Creative Commons Attribution License, which permits unrestricted use, distribution, and reproduction in any medium, provided the original work is properly cited.

\begin{abstract}
The present review summarizes the current advances in the biochemical and physiological aspects in the treatment of type 2 diabetes mellitus (DM2) with thiazolidinediones (TZDs). DM2 is a metabolic disorder characterized by hyperglycemia, triggering the abnormal activation of physiological pathways such as glucose autooxidation, polyol's pathway, formation of advance glycation end (AGE) products, and glycolysis, leading to the overproduction of reactive oxygen species (ROS) and proinflammatory cytokines, which are responsible for the micro- and macrovascular complications of the disease. The treatment of DM2 has been directed toward the reduction of hyperglycemia using different drugs such as insulin sensitizers, as the case of TZDs, which are able to lower blood glucose levels and circulating triglycerides by binding to the nuclear peroxisome proliferator-activated receptor gamma $(\operatorname{PPAR} \gamma)$ as full agonists. When TZDs interact with $\operatorname{PPAR} \gamma$, the receptor regulates the transcription of different genes involved in glucose homeostasis, insulin resistance, and adipogenesis. However, TZDs exhibit some adverse effects such as fluid retention, weight gain, hepatotoxicity, plasma-volume expansion, hemodilution, edema, bone fractures, and congestive heart failure, which limits their use in DM2 patients.
\end{abstract}

\section{Introduction}

The treatment of type 2 diabetes mellitus (DM2) has been directed toward the reduction of hyperglycemia and glycosylated hemoglobin (HbAlc, $\leq 7 \%$ ), in order to prevent cardiovascular and other long term risks $[1,2]$, specially by the usage of insulin sensitizers such as thiazolidinediones (TZDs) [1-5], an effective type of drugs for lowering blood glucose levels as circulating triglycerides [4, 6-9], with adverse effects such as adipocyte differentiation, fluid retention, weight gain, bone loss, and congestive heart failure [6-8, 10-13].

Clinically, pioglitazone is the only available TZD, even though its commercialization has been restricted to a few countries by the US Food and Drug Administration (FDA) since it may cause urinary bladder cancer. The other TZDs, rosiglitazone and troglitazone, show adverse profiles, so they are no longer available in the worldwide market; for example, rosiglitazone was associated with a significant increase in myocardial infarction, heart failure, and death from cardiovascular diseases, so the European Medicines Agency withdrew the approval for this medication in 2010, and the FDA restricted its prescription in the United States [3, 14-17].

In the present review, we summarize the current advances on the biochemical and physiological aspects involved in the treatment of DM2 with TZDs.

Type 2 Diabetes Mellitus (DM2). DM2 is a metabolic disorder characterized by hyperglycemia, which may be due to a defect 


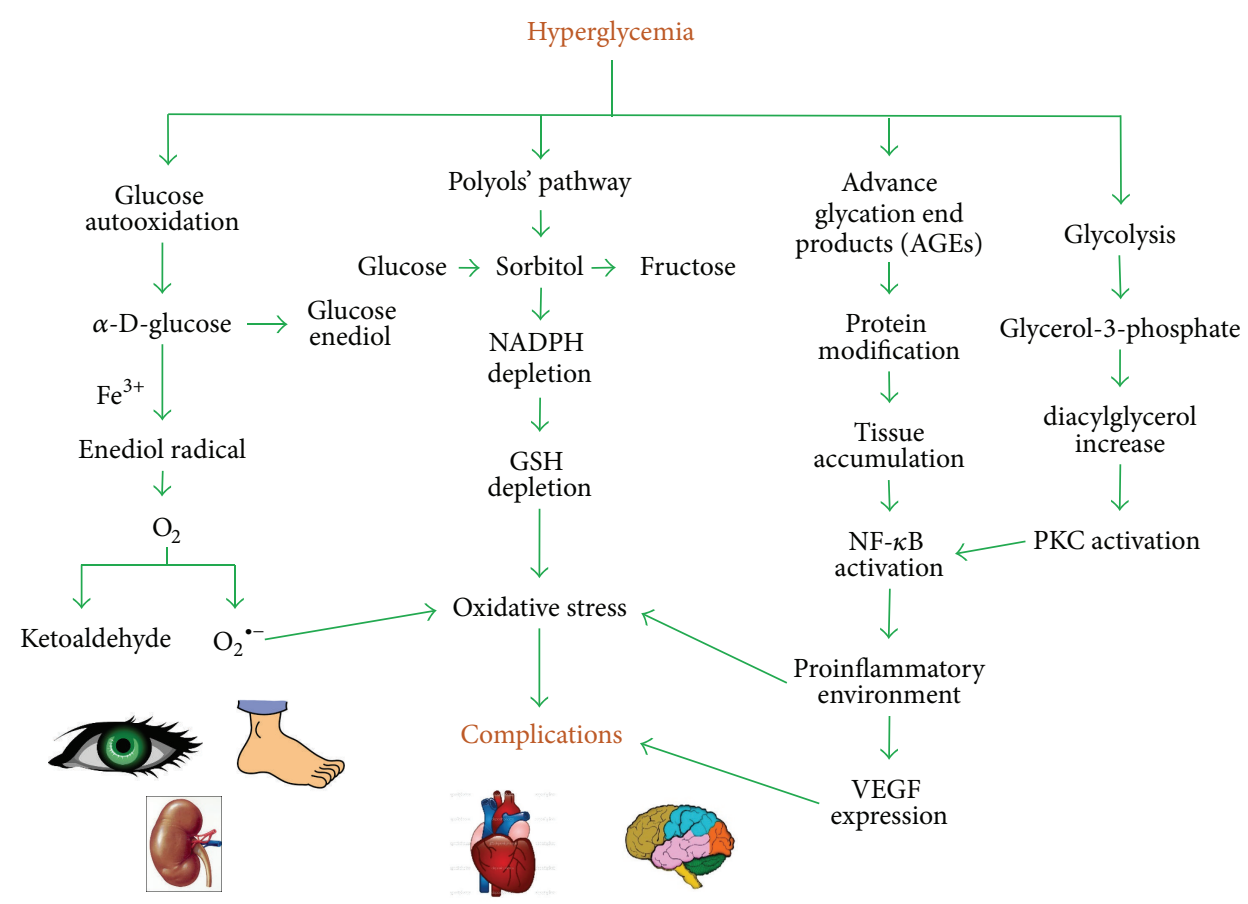

FIGURE 1: The main pathways triggered by hyperglycemia include glucose autooxidation and constant activation of polyols' pathway and formation of advance glycation end products (AGEs) and excessive glycolysis. With the constant activation of these pathways, living cells and tissues are damaged, mainly by impairment of target protein function, increase in oxidative stress, and activation of signal transduction pathways, leading to the imbalance of normal physiological functions and therefore the development of diabetic complications.

in insulin secretion of pancreatic $\beta$ cells, insulin resistance in peripheral tissues, and/or an excessive accumulation of triglycerides and fatty acid derivatives in skeletal muscles. This pathology remains a leading cause of cardiovascular disorders, such as microvascular (retinopathy, nephropathy, and neuropathy) and macrovascular (coronary, cerebrovascular, and peripheral vascular diseases) complications, mainly triggered by the abnormal activation of physiological pathways (Figure 1), and it is also associated with increased risk of cancer, psychiatric illness, cognitive decline, chronic liver disease, and development of arthritis [1-4, 18-24].

The treatment of DM2 is directed toward the reduction of hyperglycemia and HbAlc $(\leq 7 \%)$, in order to prevent cardiovascular and other long term risks (Table 1) [1, 2, 5]; there is a wide range of drugs which can be used in order to reduce glycemia, being notable mechanisms such as improving insulin secretion and reducing insulin resistance of peripheral tissues, as the case of TZDs [1-5], which are drugs targeting the peroxisome proliferator-activated receptor gamma $(\mathrm{PPAR} \gamma)$.

PPARs have emerged as links between lipids, metabolic diseases, and innate immunity as they regulate energy homeostasis $[25,26]$, and, specifically talking about PPAR $\gamma$, this receptor is capable of regulating metabolic genes which will be further discussed and improves insulin sensitivity through glucose and lipid uptake and storage in peripheral tissues such as skeletal muscle, liver, and adipose tissue [26].

The relationship between PPAR $\gamma$ and DM2 has been established using both in vitro and in vivo experimentation, since it has been seen that the inactivation of PPAR $\gamma$ in mature adipocytes leads to insulin resistance, as mice lacking the receptor develop hyperlipidemia, hyperglycemia, and/or hyperinsulinemia $[26,27]$.

Thiazolidinediones (TZDs). TZDs are compounds used clinically as insulin sensitizers in order to lower blood glucose levels as circulating triglycerides [4, 6-9], but it has also been shown that these also exhibit other biological activities such as anti-inflammatory, antimalarial, antioxidant, cytotoxic, antimicrobial, and aldose reductase inhibitor activities, either in vitro or in animal models $[10,11]$. TZDs act as peroxisome proliferator-activated receptors gamma (PPAR $\gamma)$ full agonists, which are also involved in the increase of adipocyte differentiation, fluid retention, weight gain, bone loss, and congestive heart failure. Having such diverse range of pharmacological activities, these molecules have a lot of potential uses, so different strategies have been originated to use them not only for the treatment of DM2 but also for other pathologies [2, 5, 6, 8-11].

When TZDs interact with $\operatorname{PPAR} \gamma$, the receptor regulates the transcription of different genes, mainly those genes involved in glucose homeostasis and adipogenesis, specifically within white adipose tissue (WAT) by inducing brown adipose tissue- (BAT-) like features in it, a unique characteristic exclusive for PPAR $\gamma$ full agonists, such as rosiglitazone $[13,28]$.

However, despite their excellent potencies, the incidence of undesirable side effects has been linked to the use of TZDs, 
TABLE 1: Class of drugs used for the treatment of type 2 diabetes mellitus.

\begin{tabular}{|c|c|c|c|c|c|}
\hline Class & Compounds & Mechanism & Physiological action & Advantages & Disadvantages \\
\hline Biguanides & Metformin & $\begin{array}{c}\text { Activates AMP } \\
\text { kinase }\end{array}$ & $\begin{array}{c}\downarrow \text { hepatic glucose } \\
\text { production }\end{array}$ & $\begin{array}{l}\text { Low cost, no } \\
\text { weight gain, no } \\
\text { hypoglycemia, } \\
\downarrow \text { CVD events }\end{array}$ & $\begin{array}{l}\text { Gastrointestinal } \\
\text { side effects, } \\
\text { lactic acidosis, } \\
\text { vitamin B12 } \\
\text { deficiency }\end{array}$ \\
\hline Sulfonylureas & $\begin{array}{c}\text { Glyburide } \\
\text { Glibenclamide } \\
\text { Glipizide } \\
\text { Glimepiride }\end{array}$ & $\begin{array}{l}\text { Closes K-ATP } \\
\text { channels on } \beta \\
\text { cell plasma } \\
\text { membranes }\end{array}$ & $\uparrow$ insulin secretion & $\begin{array}{l}\text { Low cost, } \\
\downarrow \text { microvascular } \\
\text { risk }\end{array}$ & $\begin{array}{l}\text { Hypoglycemia, } \\
\text { weight gain }\end{array}$ \\
\hline Meglitinides & $\begin{array}{l}\text { Repaglinide } \\
\text { Nateglinide }\end{array}$ & $\begin{array}{l}\text { Closes K-ATP } \\
\text { channels on } \beta \\
\text { cell plasma } \\
\text { membranes }\end{array}$ & $\uparrow$ insulin secretion & $\begin{array}{l}\downarrow \text { postprandial } \\
\text { glucose }\end{array}$ & $\begin{array}{l}\text { High cost, } \\
\text { hypoglycemia, } \\
\text { weight gain, } \\
\text { frequent dosing }\end{array}$ \\
\hline $\begin{array}{l}\alpha \text {-Glucosidase } \\
\text { inhibitors }\end{array}$ & $\begin{array}{l}\text { Acarbose } \\
\text { Miglitol }\end{array}$ & $\begin{array}{c}\text { Inhibits } \\
\text { intestinal } \\
\alpha \text {-glucosidase }\end{array}$ & $\begin{array}{c}\text { Slows intestinal } \\
\text { carbohydrate } \\
\text { digestion/absorption }\end{array}$ & $\begin{array}{c}\text { Moderate cost, } \\
\text { no } \\
\text { hypoglycemia, } \\
\downarrow \text { postprandial } \\
\text { glucose } \\
\downarrow \text { CVD events }\end{array}$ & $\begin{array}{l}\text { Modest HbAlc } \\
\text { efficacy, } \\
\text { gastrointestinal } \\
\text { side effects, } \\
\text { frequent dosing }\end{array}$ \\
\hline DPP4 inhibitors & $\begin{array}{c}\text { Sitagliptin } \\
\text { Vildagliptin } \\
\text { Saxagliptin } \\
\text { Linagliptin }\end{array}$ & $\begin{array}{l}\text { Inhibits DPP4 } \\
\text { activity, } \\
\text { increasing } \\
\text { postprandial } \\
\text { incretin GLP-1 } \\
\text { concentration }\end{array}$ & $\begin{array}{l}\uparrow \text { insulin secretion } \\
\downarrow \text { glucagon secretion }\end{array}$ & $\begin{array}{c}\text { No } \\
\text { hypoglycemia }\end{array}$ & $\begin{array}{l}\text { High cost, } \\
\text { modest HbAlc } \\
\text { efficacy, } \\
\text { angioedema, } \\
\text { pancreatitis }\end{array}$ \\
\hline $\begin{array}{l}\text { GLP-1 receptor } \\
\text { agonists }\end{array}$ & $\begin{array}{l}\text { Exenatide } \\
\text { Liraglutide }\end{array}$ & $\begin{array}{l}\text { Activates GLP-1 } \\
\text { receptors }\end{array}$ & $\begin{array}{c}\uparrow \text { insulin secretion } \\
\downarrow \text { glucagon secretion } \\
\uparrow \text { satiety } \\
\text { slows gastric } \\
\text { emptying } \\
\end{array}$ & $\begin{array}{c}\text { No } \\
\text { hypoglycemia, } \\
\text { weight loss }\end{array}$ & $\begin{array}{c}\text { High cost, } \\
\text { gastrointestinal } \\
\text { side effects, } \\
\text { acute } \\
\text { pancreatitis } \\
\end{array}$ \\
\hline $\begin{array}{l}\text { Bile acid } \\
\text { sequestrants }\end{array}$ & Colesevelam & $\begin{array}{l}\text { Binds bile acids } \\
\text { in intestinal } \\
\text { tract, increasing } \\
\text { hepatic bile acid } \\
\text { production }\end{array}$ & $\begin{array}{c}\downarrow \text { hepatic glucose } \\
\text { production } \\
\uparrow \text { incretin levels }\end{array}$ & $\begin{array}{c}\text { No } \\
\text { hypoglycemia } \\
\downarrow \text { LDL }\end{array}$ & $\begin{array}{c}\text { High cost, } \\
\text { modest HbAlc } \\
\text { efficacy, } \\
\text { constipation } \\
\uparrow \text { triglycerides } \\
\end{array}$ \\
\hline $\begin{array}{l}\text { Dopamine } 2 \\
\text { agonists }\end{array}$ & Bromocriptine & $\begin{array}{l}\text { Activates } \\
\text { dopaminergic } \\
\text { receptors }\end{array}$ & $\begin{array}{c}\text { Modulates } \\
\text { hypothalamic } \\
\text { regulation of } \\
\text { metabolism } \\
\uparrow \text { insulin sensitivity }\end{array}$ & $\begin{array}{c}\text { No } \\
\text { hypoglycemia } \\
\downarrow \text { CVD events }\end{array}$ & $\begin{array}{c}\text { High cost, } \\
\text { modest HbAlc } \\
\text { efficacy, } \\
\text { dizziness, } \\
\text { syncope, nausea, } \\
\text { fatigue }\end{array}$ \\
\hline Thiazolidinediones & $\begin{array}{l}\text { Pioglitazone } \\
\text { Rosiglitazone }\end{array}$ & $\begin{array}{l}\text { Activates the } \\
\text { nuclear } \\
\text { transcription } \\
\text { factor PPAR } \gamma\end{array}$ & $\uparrow$ insulin sensitivity & $\begin{array}{c}\text { No } \\
\text { hypoglycemia } \\
\uparrow \text { HDL } \\
\downarrow \text { triglycerides } \\
\downarrow \text { CVD events }\end{array}$ & $\begin{array}{c}\text { High cost, } \\
\text { weight gain, } \\
\text { edema/heart } \\
\text { failure, bone } \\
\text { fractures, } \\
\text { bladder cancer } \\
\text { (pioglitazone) } \\
\uparrow \text { LDL }\end{array}$ \\
\hline Insulin & $\begin{array}{c}\text { Human NPH } \\
\text { Human regular } \\
\text { Lispro } \\
\text { Aspart } \\
\text { Glulisine } \\
\text { Glargine } \\
\text { Detemir } \\
\text { Premixed } \\
\end{array}$ & $\begin{array}{l}\text { Activates insulin } \\
\text { receptors }\end{array}$ & $\begin{array}{c}\uparrow \text { glucose disposal } \\
\downarrow \text { hepatic glucose } \\
\text { production }\end{array}$ & $\begin{array}{c}\text { Universally } \\
\text { effective } \\
\downarrow \text { microvascular } \\
\text { risk }\end{array}$ & $\begin{array}{l}\text { Variable cost, } \\
\text { hypoglycemia, } \\
\text { weight gain }\end{array}$ \\
\hline
\end{tabular}


such as fluid retention, weight gain, hepatotoxicity (only for troglitazone), plasma-volume expansion, hemodilution, edema, and congestive heart failure; it is unknown if the toxicity is mediated by the activation of PPAR $\gamma$ or if it is due to some other mechanism unique to the TZD drug, since neither rosiglitazone nor pioglitazone has displayed the increased incidence of hepatic adverse events seen with troglitazone, suggesting that hepatotoxicity may not be a class effect of PPAR $\gamma$ agonists $[6,7,29-32]$; it has been proposed that the fluid adverse effects may be due to the regulation of PPAR $\gamma$ through an unknown mechanism involved in the enhancement of urinary vasopressin excretion response [3335].

Peroxisome Proliferator-Activated Receptors (PPARs). PPARs are nuclear receptors that belong to the thyroid/retinoid nuclear family which act as ligand activated transcription factors. Three isoforms for these receptors have been described, $\alpha, \beta / \delta$, and $\gamma$, regulating tissue specific target genes involved in biological pathways for lipid and glucose homeostasis. PPAR $\alpha$ is expressed predominantly in the liver, heart, and BAT, where it expresses genes involved in fatty acid oxidation; its exogenous ligands are the hypolipidemic fibrate drugs. PPAR $\beta / \delta$ is expressed in all kinds of tissues and has a crucial role in fatty acid oxidation, mainly in skeletal muscle, liver, and heart. PPAR $\gamma$ is highly expressed in both WAT and BAT, where it functions as a regulator of adipogenesis and as a modulator of lipid metabolism and insulin sensitivity. Activation of PPAR $\gamma$ is crucial for controlling gene networks involved in glucose homeostasis, including increasing the expression of glucose transporter type 4 (GLUT4), adiponectin, resistin, and tumor necrosis factor $\alpha(\mathrm{TNF} \alpha)$, which negatively influence insulin sensitivity. All three isotypes of PPARs, but mainly PPAR $\gamma$, are ligand activated transcription factors implicated in the physiopathology of various diseases including DM2, obesity, dyslipidemia, atherosclerosis, neoplastic diseases, tumors, inflammatory conditions, and neurodegenerative diseases by forming obligate heterodimers with the retinoid X receptor (RXR), promoting the dissociation of corepressors, recruitment of coactivators, and the subsequent transcription of target genes [3, 6, 12, 13, 36-42].

So far, three isoforms for PPAR $\gamma$ have been described, $\gamma 1$, $\gamma 2$, and $\gamma 3$, which arise as the product of different promoter usage. mRNA of PPAR $\gamma 1$ and PPAR $\gamma 3$ code for the same protein, while PPAR $\gamma 2$ codes for a different protein containing $30 \mathrm{NH}_{2}$-terminal amino acids due to an alternative promoter usage and mRNA splicing, but no physiologically relevant differences in the function of these two isoforms have been determined $[9,29,37,38,43]$. PPAR $\gamma$ is organized in main functional domains. The amino terminal $\mathrm{A} / \mathrm{B}$ domain contains a ligand dependent transactivation function (AF1), while the $\mathrm{C}$ domain is the central DNA binding domain by containing two zinc finger-like structures and one $\alpha$ helical DNA binding motif; the E/F domain is the ligand binding domain (LBD), which contains a ligand dependent transactivation function (AF-2), which allows the receptors' conformational changes in the presence of the ligand, leading to the recruitment of coactivators, such as the steroid receptor

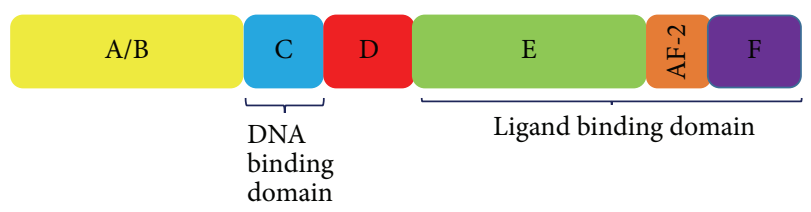

FIgUre 2: Main functional domains of nuclear PPARs. All three isotypes of PPAR have 4 main functional domains: $A / B$, which is the activation function 1 (AF-1); $\mathrm{C}$, or DNA binding domain; $\mathrm{D}$, which serves as a hinge between $\mathrm{C}$ and $\mathrm{E} / \mathrm{F}$; and $\mathrm{E} / \mathrm{F}$, which includes $\mathrm{AF}-2$, a ligand binding dimerization transactivation domain.

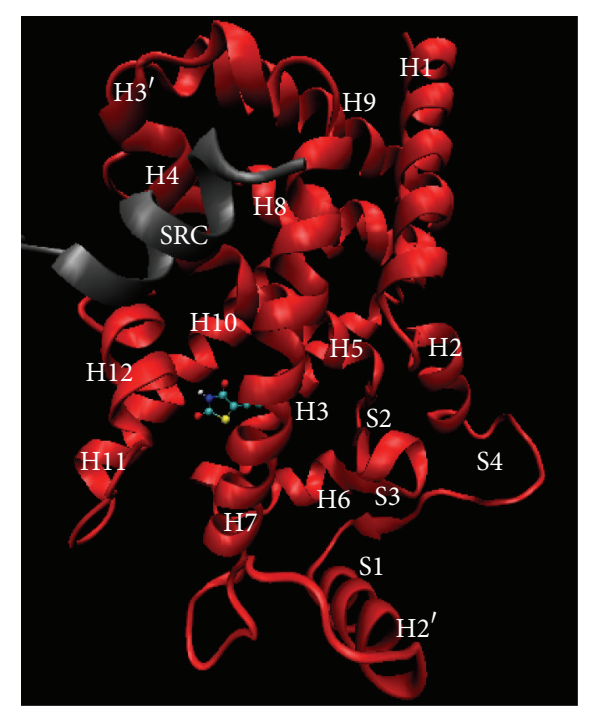

Figure 3: Crystal structure of PPAR $\gamma$ (PDB: 2PRG entry), cocrystalized with rosiglitazone (ligand) and steroid receptor coactivator 1 (SRC-1, coactivator). Figure constructed using Visual Molecular Dynamics (VMD) software.

coactivator type 1 (SRC-1), and the release of corepressors (Figure 2) [12, 44-47].

The PPAR $\gamma$ LBD contains a large binding pocket that allows a wide range of ligands searching for their proper conformations in order to form ligand-receptor complexes. Natural ligands of PPAR $\gamma$ are fatty acids, while synthetic ligands can be classified as either full or partial agonists, such as TZDs, L-tyrosine analogs, and some nonsteroidal anti-inflammatory drugs $[7,8,12,30,31,39,44,48-50]$. The structure of the LBD is comprised of 13 helices and $4 \beta$ sheets, with a total volume of approximately 1300 to $1400 \AA$. The cavity is $\mathrm{Y}$ shaped, consisting of an entrance which extends from the surface of the protein, and then it branches off into two arms, arm I, which extends toward the AF-2 (helix H12), and arm II, situated between helix $\mathrm{H} 3$ and the $\beta$ sheet (Figure 3) [44, 45, 47, 51]. An important step during the activation process involves ligand-induced alteration of the conformation of $\mathrm{H} 12$ to an active position. The main model for ligand dependent activation of nuclear receptors proposes that agonists stabilize a specific conformation of the AF2 (H12) helix, which, along with helices 3 and 4, provides a suitable interface for binding a coactivator, acting as a 


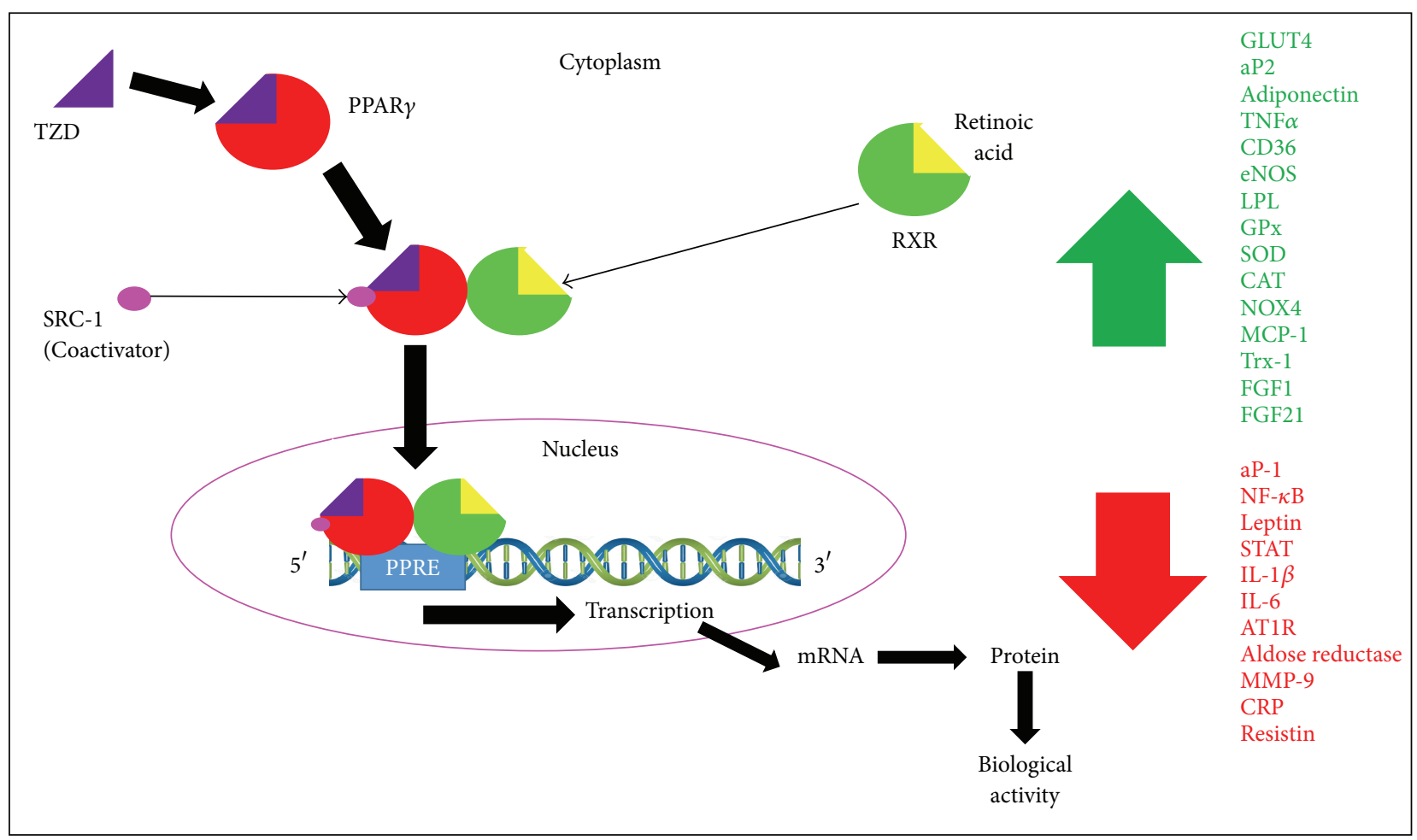

FIGURE 4: Mechanism of action of PPAR $\gamma$ when it is activated by its exogenous ligands thiazolidinediones (TZDs).

molecular switch and creating a binding cleft on the receptor for the coactivator $[8,13,45]$.

TZDs are one of the most known PPAR $\gamma$ agonists. They share common features such as a hydrophilic head group, a central hydrophobic body, and a flexible linker to a cyclic tail. The hydrophilic head group can have a hydroxyl, carbonyl, or carboxyl oxygen atoms, allowing it to form $\mathrm{H}$ bonds with the key amino acid residues Tyr 473, (AF2, H12), His 449 (H11), His323 (H5), Ser289 (H3), and Gln286 (H3) of the LBD, generating an intermolecular network exclusive for full agonists. These $\mathrm{H}$ bond networks stabilize the receptor in the proper conformation; however, the acid head group of commercially available TZDs is prone to racemization under physiological conditions due to its stereogenic center at C5, and it has been demonstrated that only the (S)-enantiomers bind to the receptor, which suggests that approximately $50 \%$ of the active substance is inactive. Binding of these ligands results in conformational changes of the receptors that facilitate their interaction with coactivator proteins. The resulting complexes activate the transcription of specific target genes, resulting in the induction of signaling cascades that mediate the physiological effects of the ligands (Figure 4) [7-10, 12, 29-31, 39, 43, 44, 47-52].

PPAR $\gamma$ and Inflammatory Diseases. Both PPAR $\alpha$ and PPAR $\gamma$ isotypes participate in the regulation of inflammation processes. PPAR $\alpha$ regulates primarily catabolic and PPAR $\gamma$ regulates primarily anabolic aspects of lipid metabolism [13, $29,43]$.
Prostaglandin J2 (PGJ2) activation of PPAR $\gamma$ has been demonstrated to antagonize the activity of activator protein type 1 (aP-1) which enhances the angiogenic response seen in the diabetic microvascular complications [53] and the signal transducer and activator of transcription (STAT) protein which regulates the inflammation cascade [54] and the nuclear factor $\kappa \mathrm{B}(\mathrm{NF}-\kappa \mathrm{B})$ which also regulates the inflammation cascade mainly in adipocytes [51]; these are known for their positive control on cytokine gene expression $[6,12,36,37,39-41]$.

Diverse theories propose the molecular mechanisms by which PPAR $\gamma$ exhibits anti-inflammatory effects; among these theories, it can be mentioned that the expression of the receptor is upregulated by oxidized low density lipoproteins (LDL) in macrophages, which will in turn stimulate the expression of the cluster of differentiation 36 (CD36) scavenger receptor gene, resulting in a higher rate of oxidized LDL internalization, which, besides serving as a fatty acid transporter, is a novel biomarker for DM2 $[55,56]$, but it is also postulated that the expressions of inflammatory mediators such as tumor necrosis factor $\alpha(\mathrm{TNF} \alpha)$, interleukin 6 (IL6), and matrix metallopeptidase 9 (MMP-9) are negatively controlled by PPAR $\gamma$, which in turn takes importance for the development of atherosclerosis [50,57]. It is also possible that PPAR $\gamma$ ligands act as anti-inflammatory and antioxidant agents through the inhibition of the transcription factor NF$\kappa \mathrm{B} / \mathrm{p} 65$ and the expression of NADPH oxidase 4 (NOX4), thus reducing the levels of IL-6, C-reactive protein (CRP), and monocyte chemoattractant protein 1 (MCP-1), but it 
has also been postulated that PPAR $\gamma$ activation directly regulates the expression of endogenous antioxidants such as superoxide dismutase (SOD), catalase (CAT), glutathione peroxidase (GPx), and thioredoxin (Trx-1), therefore playing a crucial role in cardiac redox balance [58-61].

Since diabetic vascular complications are partly mediated by inflammatory processes, the use of TZDs may contribute positively to patients' outcomes since insulin sensitizers suppress the inflammatory processes not only through lowering hyperglycemia but also by modulating the expression of key inflammatory biomarkers as can be seen in Figure 1. These effects may be potentiated when TZDs are used along with other drugs, for example, statins, fibrates, and inhibitors of renin-angiotensin-aldosterone system, which reduce the overall risk for DM2 [62, 63].

It also has been seen that TZDs may exert antiatherogenic effects on vessel wall cells, possibly by downregulating NF- $\kappa$ B inflammatory pathways $[62,63]$.

PPAR $\gamma$ and Metabolic Disorders. PPAR $\gamma$ is predominately expressed in adipose tissue, but it is also expressed in the lungs, placenta, heart, and leukocytes, where it regulates lipid, glucose, and insulin uptake into adipocytes, as it is responsible for regulating the expression of two markers of terminal adipocyte differentiation, adipocyte protein type $2(\mathrm{aP}-2)$ and phosphoenolpyruvate carboxykinase. PPAR $\gamma$ is also in charge of regulating the expression of the genes which code for lipoprotein lipase (LPL), increasing triglycerides lipolysis in very low density lipoproteins (VLDLs) and increasing high density lipoproteins (HDLs) [62], the fatty acid transport protein, which regulates fatty acid uptake, and fatty acid translocase, which enhances fatty acid uptake in adipocytes, as the repression of the expression of the $o b$ gene for leptin, which increases the appetite (Figure 4), and this is concordant with the physiological effects of TZDs, such as lowering blood glucose levels and improving insulin sensitivity $[3,12,13$, $29,32,42,57]$. However, adipogenesis caused in response to treatment with TZDs has been linked mainly to the identification of two PPAR $\gamma$-responsive members of the fibroblast growth factor family, fibroblast growth factor 1 (FGF1) and fibroblast growth factor 21 (FGF21), which act locally in visceral adipose tissue, promoting insulin sensitization, so that the activation of the receptor in the brain, rather than in adipose tissue, has a major role in TZD-induced weight gain [13].

Obesity rates and westernization of lifestyle lead to the increase of dysfunctional adipose tissue, which constantly activates NF- $\kappa \mathrm{B}$ and delivers inflammatory cytokines such as $\mathrm{TNF} \alpha$, resistin, IL-6, and IL- $1 \beta$, which, along with the impairment of reactive oxygen species (ROS) and water retention, are mainly present in a wide range of diseases like insulin resistance, DM2, hypertension, hyperlipidemia, and cardiovascular diseases (CVD), therefore maintaining a chronic inflammatory environment $[1,14,58,64-67]$.

Insulin resistance has been identified as a major contributor to the development of DM2 and metabolic syndrome since it increases the delivery of fatty acids (FA) into the circulation, which modulate the ability of the heart to use glucose as a source of energy [59,66, 68-71] leading to a cellular stress characterized by an excessive ROS production, impaired state of nitric oxide (NO) vasorelaxation, production of inflammatory cytokines, mitochondrial dysfunction, increased advanced glycation end products (AGEs), and dysfunction of endothelial progenitor cells, as the inhibition of the antiatherogenic adipokine adiponectin $[15,59,64,66$, 68-72].

PPAR $\gamma$ is highly expressed in the vascular system, where it is involved in the repression or expression of certain genes such as angiotensin type 1 receptor (AT1R), which can prevent or ameliorate endothelial dysfunction and atherosclerosis $[3,15,16,60,67,73,74]$. In accordance with this, it has been seen that, in animal models, repression of the expression of PPAR $\gamma$ promotes cardiomyopathy, lipid deposition, arrhythmias, hypertrophy, and increased expression of cardiac inflammatory markers $[61,66,70,71]$. It has also been shown that adiponectin increases through PPAR-responsive element in the promoter of adipocytes, playing an essential role for the vascular protective effects of PPAR $\gamma$ agonists, as the case where diabetic $d b / d b$ mice treated with rosiglitazone stimulated the release of adiponectin, which activated AMP activated protein kinase (AMPK/eNOS) and protein kinase A (cAMP/PKA) pathways in the aorta, consequently leading to the reduction of oxidative stress and the enhancement of NO bioavailability, improving endothelial function $[15,58,75]$. It has also been seen either in clinical practice or in animal models that the continuous treatment with TZDs tends to attenuate the progression of carotid artery intima/media thickness, reducing the onset of restenosis, mainly due to the inhibition of smooth cell migration, the increased apoptosis in vascular smooth cells, and the prevention of insulin driven atherosclerosis by switching myocardial substrate metabolism toward glucose $[14,70,73,74,76]$.

PPARY and Cardiovascular Diseases. CVD and DM2 are intimately linked as they share some pathophysiological features [76], for example, the development of atherosclerosis, which may lead to myocardial infarction, coronary heart disease, peripheral artery disease, and critical limb ischemia [77].

It has been previously found that CVD increase the rate of cardiovascular death nearly fivefold in subjects with diabetes, mainly due to myocardial infarction. Also, the relevance of diabetes for the development of atherosclerosis has been made clear through the observation that a majority of patients with coronary heart disease have insulin resistance or have been diagnosed with frank diabetes $[77,78]$.

The use of TZDs has been controversial in terms of prevention of CVD, since it has been shown that these types of drugs induce and maintain the regression of carotid intimamedia thickness in patients with type 2 diabetes, as they have been related to anti-inflammatory and antiproliferative activities in smooth muscle cells, inhibiting the atheromatous plaque progression [13,77]. Another substantial side effect of TZDs is the fluid retention with associated peripheral edema by the alteration of sodium and water reabsorption in the distal collecting ducts of the kidney, which increases the risk for adverse cardiovascular events, such as congestive heart failure [13]. 
PPAR $\gamma$ and Bone Fractures. The use of TZDs has been related to bone fractures, especially rosiglitazone, which exhibited an increased risk of fractures in comparison with patients receiving metformin or glyburide [28]. On the other hand, pioglitazone exhibited an increased incidence of distal extremity fractures on the PRO-active trial [3]. These fractures may be due to the expression of PPAR $\gamma$ in bone narrow stromal cells, osteoblasts, and osteoclasts [28], which promotes an alteration on the mesenchymal stem cell maturation, leading to a shift from an osteoblastic lineage to the adipogenic lineage, which turns into an accumulation of ROS and apoptosis of the cells in the osteogenic lineage, thereby decreasing bone formation $[13,28]$.

\section{Conclusions}

A great number of studies have shown that the activation of PPAR $\gamma$ is implicated in the development of undesirable adverse effects such as fluid retention, weight gain, hepatotoxicity, plasma-volume expansion, hemodilution, edema, bone fractures, and congestive heart failure, but it is also involved in the prevention of developing atherosclerosis, even though there are certainly another great number of studies which can demonstrate the opposite and also confirm that some agonists of the receptor, specifically rosiglitazone, may increase CVD risk. We believe that the associated risk of CVD during TZDs therapy may be related to different transcription patterns in the PPAR $\gamma$ activation due to different ligands, since troglitazone and pioglitazone do not increase CVD risk, as pioglitazone may cause bladder cancer, or rosiglitazone or troglitazone or hepatotoxicity, which is directly correlated to the use of troglitazone or the other TZDs, as they interact in different ways with the receptor and therefore induce different conformations and different interactions with coactivators/corepressors, as different interactions with the responsive element, therefore triggering the transcription of diverse genes. According to these, it would be important to investigate the different conformations of the receptor in the presence of different ligands, either endogenous or exogenous, so that it would be possible to predict which coactivator or corepressor is more susceptible to be recruited, as the possible biochemical and physiological effects of each one. By doing this prediction, it would be possible to design better ligands derived from TZDs with less adverse effects, and it would also be possible to use them for the treatment of other diseases such as cancer, metabolic syndrome, hypertension, obesity, and even CVD.

\section{Disclosure}

The authors alone are responsible for the content and writing of the paper.

\section{Competing Interests}

The authors have no conflict of interests in the use of materials or techniques mentioned in this review.

\section{Acknowledgments}

The authors are grateful to Secretaría de Investigación y Posgrado, IPN (SIP20161383/SIP20160675), CONACyT (I010/ 0532/2014), SIBE (COFFA), and EDI (SIP)/IPN, México.

\section{References}

[1] S. E. Inzucchi, R. M. Bergenstal, J. B. Buse et al., "Management of hyperglycemia in type 2 diabetes: a patient-centered approach position statement of the American Diabetes Association (ADA) and the European Association for the Study of Diabetes (EASD)," Diabetes Care, vol. 35, no. 6, pp. 1364-1379, 2012.

[2] A. Qaseem, L. L. Humphrey, D. E. Sweet, M. Starkey, and P. Shekelle, "Oral pharmacologic treatment of type 2 diabetes mellitus: a clinical practice guideline from the American college of physicians," Annals of Internal Medicine, vol. 156, no. 3, pp. 218-231, 2012.

[3] B. Grygiel-Górniak, "Peroxisome proliferator-activated receptors and their ligands: nutritional and clinical implications-a review," Nutrition Journal, vol. 13, article 17, 10 pages, 2014.

[4] S. Alex, K. Lange, T. Amolo et al., "Short-chain fatty acids stimulate angiopoietin-like 4 synthesis in human colon adenocarcinoma cells by activating peroxisome proliferator-activated receptor $\gamma$," Molecular and Cellular Biology, vol. 33, no. 7, pp. 1303-1316, 2013.

[5] A. A. Onitilo, J. M. Engel, I. Glurich, R. V. Stankowski, G. M. Williams, and S. A. Doi, "Diabetes and cáncer II: role of diabetes medications and influence of shared risk factors," Cancer Causes \& Control, vol. 23, no. 7, pp. 991-1008, 2012.

[6] R. K. Petersen, K. B. Christensen, A. N. Assimopoulou et al., "Pharmacophore-driven identification of PPAR $\gamma$ agonists from natural sources," Journal of Computer-Aided Molecular Design, vol. 25, no. 2, pp. 107-116, 2011.

[7] H. J. Gim, H. Li, E. Lee, J.-H. Ryu, and R. Jeon, "Design and synthesis of alkoxyindolyl-3-acetic acid analogs as peroxisome proliferator-activated receptor- $\gamma / \delta$ agonists," Bioorganic \& Medicinal Chemistry Letters, vol. 23, no. 2, pp. 513-517, 2013.

[8] J. C. Dos Santos, A. Bernardes, L. Giampietro et al., "Different binding and recognition modes of GL479, a dual agonist of Peroxisome Proliferator-Activated Receptor $\alpha / \gamma$," Journal of Structural Biology, vol. 191, no. 3, pp. 332-340, 2015.

[9] F. A. Monsalve, R. D. Pyarasani, F. Delgado-Lopez, and R. Moore-Carrasco, "Peroxisome proliferator-activated receptor targets for the treatment of metabolic diseases," Mediators of Inflammation, vol. 2013, Article ID 549627, 18 pages, 2013.

[10] V. R. Avupati, R. P. Yejella, A. Akula et al., "Synthesis, characterization and biological evaluation of some novel 2,4thiazolidinediones as potential cytotoxic, antimicrobial and antihyperglycemic agents," Bioorganic \& Medicinal Chemistry Letters, vol. 22, no. 20, pp. 6442-6450, 2012.

[11] S. Mandard and D. Patsouris, "Nuclear control of the inflammatory response in mammals by peroxisome proliferator-activated receptors," PPAR Research, vol. 2013, Article ID 613864, 23 pages, 2013.

[12] J. A. Youssef and M. Z. Badr, "Peroxisome proliferator-activated receptors: discovery and recent advances," in Peroxisome Proliferator-Activated Receptors, chapter 3, Springer, 2013.

[13] M. Ahmadian, J. M. Suh, N. Hah et al., "PPAR $\gamma$ signaling and metabolism: the good, the bad and the future," Nature Medicine, vol. 19, no. 5, pp. 557-566, 2013. 
[14] H. M. García-García, S. Garg, S. Brugaletta et al., "Evaluation of in-stent restenosis in the APPROACH trial (assessment on the prevention of progression by Rosiglitazone on atherosclerosis in diabetes patients with cardiovascular history)," The International Journal of Cardiovascular Imaging, vol. 28, no. 3, pp. 455465, 2012.

[15] P. Balakumar and S. Kathuria, "Submaximal PPAR $\gamma$ activation and endothelial dysfunction: new perspectives for the management of cardiovascular disorders," British Journal of Pharmacology, vol. 166, no. 7, pp. 1981-1992, 2012.

[16] Y. Atamer, A. Atamer, A. S. Can et al., "Effects of rosiglitazone on serum paraoxonase activity and metabolic parameters in patients with type 2 diabetes mellitus," Brazilian Journal of Medical and Biological Research, vol. 46, no. 6, pp. 528-532, 2013.

[17] Y. Lu, D. Ma, W. Xu, S. Shao, and X. Yu, "Effect and cardiovascular safety of adding rosiglitazone to insulin therapy in type 2 diabetes: a meta-analysis," Journal of Diabetes Investigation, vol. 6, no. 1, pp. 78-86, 2015.

[18] M. M. Elmazar, H. S. El-Abhar, M. F. Schaalan, and N. A. Farag, "Phytol/phytanic acid and insulin resistance: potential role of phytanic acid proven by docking simulation and modulation of biochemical alterations," PLoS ONE, vol. 8, no. 1, Article ID e45638, 2013.

[19] V. A. Dixit and P. V. Bharatam, "SAR and computer-aided drug design approaches in the discovery of peroxisome proliferatoractivated receptor $\gamma$ activators: a perspective," Journal of Computational Medicine, vol. 2013, Article ID 406049, 38 pages, 2013.

[20] M. Takahashi, "Glycation of proteins," in Glycoscience: Biology and Medicine, pp. 1339-1345, Springer, Berlin, Germany, 2015.

[21] M. A. Babizhayev, I. A. Strokov, V. V. Nosikov et al., "The role of oxidative stress in diabetic neuropathy: generation of free radical species in the glycation reaction and gene polymorphisms encoding antioxidant enzymes to genetic susceptibility to diabetic neuropathy in population of type I diabetic patients," Cell Biochemistry and Biophysics, vol. 71, no. 3, pp. 1425-1443, 2015.

[22] M. Soltesova-Prnova, J. Ballekova, A. Gajdosikova, A. Gajdosik, and M. Stefek, "A novel carboxymethylated mercaptotriazinoindole inhibitor of aldose reductase interferes with the polyol pathway in streptozotocin-induced diabetic rats," Physiological Research, vol. 64, no. 4, pp. 587-591, 2015.

[23] A. K. Tiwari, D. A. Kumar, P. S. R. Sweeya et al., "Vegetables' juice influences polyol pathway by multiple mechanisms in favour of reducing development of oxidative stress and resultant diabetic complications," Pharmacognosy Magazine, vol. 10, no. 38, pp. 383-391, 2014.

[24] K. M. Juskova, P. M. Soltesova, and M. Stefek, "A novel zwitterionic inhibitor of aldose reductase interferes with polyol pathway in an ex vivo and in vivo models of diabetic complications," Pharmazie, vol. 69, no. 10, pp. 747-751, 2014.

[25] W. Wahli and L. Michalik, "PPARs at the crossroads of lipid signaling and inflammation," Trends in Endocrinology \& Metabolism, vol. 23, no. 7, pp. 351-363, 2012.

[26] S.-S. Choi, J. Park, and J. H. Choi, "Revisiting PPAR $\gamma$ as a target for the treatment of metabolic disorders," BMB Reports, vol. 47, no. 11, pp. 599-608, 2014.

[27] R. N. Lamounier, C. N. Coimbra, P. White et al., "Apoptosis rate and transcriptional response of pancreatic islets exposed to the PPAR gamma agonist pioglitazone," Diabetology \& Metabolic Syndrome, vol. 5, no. 1, pp. 1-10, 2013.

[28] J. P. Bilezikian, R. G. Josse, R. Eastell et al., "Rosiglitazone decreases bone mineral density and increases bone turnover in postmenopausal women with type 2 diabetes mellitus," The Journal of Clinical Endocrinology \& Metabolism, vol. 98, no. 4, pp. 1519-1528, 2013.

[29] V. A. Verma, B. Halu, and V. R. Kulkarni, "Understanding the antihyperglycemic agents of thiazolidinediones analogues using quantitative structure activity relationship (QSAR) models," World Journal of Pharmaceutical Sciences, vol. 3, no. 3, pp. 22122221, 2014.

[30] M.-C. Cho, D.-H. Lee, E. J. Kim et al., "Novel PPAR $\gamma$ partial agonists with weak activity and no cytotoxicity, identified by a simple PPAR $\gamma$ ligand screening system," Molecular and Cellular Biochemistry, vol. 358, no. 1-2, pp. 75-83, 2011.

[31] L. Wang, B. Waltenberger, E.-M. Pferschy-Wenzig et al., "Natural product agonists of peroxisome proliferator-activated receptor gamma (PPAR $\gamma$ ): a review," Biochemical Pharmacology, vol. 92, no. 1, pp. 73-89, 2014.

[32] B. FCariou, R. Hanf, S. Lambert-Porcheron et al., "Dual peroxisome proliferator-activated receptor $\alpha / \delta$ agonist GFT505 improves hepatic and peripheral insulin sensitivity in abdominally obese subjects," Diabetes Care, vol. 36, no. 10, pp. 29232930, 2013.

[33] L. Zhou, A. Panasiuk, M. Downton et al., "Systemic PPAR $\gamma$ deletion causes severe disturbance in fluid homeostasis in mice," Physiological Genomics, vol. 47, no. 11, pp. 541-547, 2015.

[34] L. Zhou, G. Liu, Z. Jia et al., "Increased susceptibility of $\mathrm{db} / \mathrm{db}$ mice to rosiglitazone-induced plasma volume expansion: role of dysregulation of renal water transporters," American Journal of Physiology-Renal Physiology, vol. 305, no. 10, pp. F1491-F1497, 2013.

[35] S. Horita, M. Nakamura, N. Satoh, M. Suzuki, and G. Seki, "Thiazolidinediones and edema: recent advances in the pathogenesis of thiazolidinediones-induced renal sodium retention," PPAR Research, vol. 2015, Article ID 646423, 7 pages, 2015.

[36] S. Hidalgo-Figueroa, J. J. Ramírez-Espinosa, S. Estrada-Soto et al., "Discovery of thiazolidine-2,4-dione/biphenylcarbonitrile hybrid as dual ppar $\alpha / \gamma$ modulator with antidiabetic effect: in vitro, in silico and in vivo approaches," Chemical Biology \& Drug Design, vol. 81, no. 4, pp. 474-483, 2013.

[37] H. Zhang, C. Z. Ding, Z. Lai et al., "Synthesis and biological evaluation of novel pyrrolidine acid analogs as potent dual PPAR $\alpha / \gamma$ agonists," Bioorganic \& Medicinal Chemistry Letters, vol. 25, no. 6, pp. 1196-1205, 2015.

[38] J. Ye, "Mechanisms of insulin resistance in obesity," Frontiers of Medicine, vol. 7, no. 1, pp. 14-24, 2013.

[39] A. Carrieri, M. Giudici, M. Parente et al., "Molecular determinants for nuclear receptors selectivity: chemometric analysis, dockings and site-directed mutagenesis of dual peroxisome proliferator-activated receptors $\alpha / \gamma$ agonists," European Journal of Medicinal Chemistry, vol. 63, pp. 321-332, 2013.

[40] A. Laghezza, G. Pochetti, A. Lavecchia et al., "New 2-(aryloxy)3-phenylpropanoic acids as peroxisome proliferator-activated receptor $\alpha / \gamma$ dual agonists able to upregulate mitochondrial carnitine shuttle system gene expression," Journal of Medicinal Chemistry, vol. 56, no. 1, pp. 60-72, 2013.

[41] P. García-Rojas, A. Antaramian, L. González-Dávalos et al., "Induction of peroxisomal proliferator-activated receptor $\gamma$ and peroxisomal proliferator-activated receptor $\gamma$ coactivator 1 by unsaturated fatty acids, retinoic acid, and carotenoids in preadipocytes obtained from bovine white adipose tissue," Journal of Animal Science, vol. 88, no. 5, pp. 1801-1808, 2010.

[42] I. J. Lodhi, L. Yin, A. P. L. Jensen-Urstad et al., "Inhibiting adipose tissue lipogenesis reprograms thermogenesis and PPAR $\gamma$ 
activation to decrease diet-induced obesity," Cell Metabolism, vol. 16, no. 2, pp. 189-201, 2012.

[43] R. M. Evans and D. J. Mangelsdorf, "Nuclear receptors, RXR, and the big bang," Cell, vol. 157, no. 1, pp. 255-266, 2014.

[44] L. Zhang, X.-M. Ren, B. Wan, and L.-H. Guo, "Structuredependent binding and activation of perfluorinated compounds on human peroxisome proliferator-activated receptor $\gamma$," Toxicology and Applied Pharmacology, vol. 279, no. 3, pp. 275-283, 2014.

[45] T. S. Hughes, M. J. Chalmers, S. Novick et al., "Ligand and receptor dynamics contribute to the mechanism of graded PPAR $\gamma$ agonism," Structure, vol. 20, no. 1, pp. 139-150, 2012.

[46] J. Burston and D. Kendall, "Peroxisome proliferator-activated receptors and inflammation," in endoCANNABINOIDS: Actions at Non- $C B_{1} / C B_{2}$ Cannabinoid Receptors, M. E. Abood, R. G. Sorensen, and N. Stella, Eds., vol. 24 of The Receptors, pp. 221233, 2012.

[47] A. J. Kroker and J. B. Bruning, "Review of the structural and dynamic mechanisms of PPAR $\gamma$ partial agonism," PPAR Research, vol. 2015, Article ID 816856, 15 pages, 2015.

[48] B. Xiao, J. Yin, M. Park et al., "Design and synthesis of marine fungal phthalide derivatives as PPAR- $\gamma$ agonists," Bioorganic and Medicinal Chemistry, vol. 20, no. 16, pp. 4954-4961, 2012.

[49] A. Georgiadi and S. Kersten, "Mechanisms of gene regulation by fatty acids," Advances in Nutrition, vol. 3, no. 2, pp. 127-134, 2012.

[50] H. J. Gim, Y.-J. Cheon, J.-H. Ryu, and R. Jeon, “Design and synthesis of benzoxazole containing indole analogs as peroxisome proliferator-activated receptor- $\gamma / \delta$ dual agonists," Bioorganic \& Medicinal Chemistry Letters, vol. 21, no. 10, pp. 3057-3061, 2011.

[51] D. Moras, I. M. L. Billas, N. Rochel, and B. P. Klaholz, "Structure-function relationships in nuclear receptors: the facts," Trends in Biochemical Sciences, vol. 40, no. 6, pp. 287-290, 2015.

[52] P. Ketsawatsomkron and C. D. Sigmund, "Molecular mechanisms regulating vascular tone by peroxisome proliferator activated receptor gamma," Current Opinion in Nephrology and Hypertension, vol. 24, no. 2, pp. 123-130, 2015.

[53] J. Jia, T. Ye, P. Cui, Q. Hua, H. Zeng, and D. Zhao, "AP-1 transcription factor mediates VEGF-induced endothelial cell migration and proliferation," Microvascular Research, vol. 105, pp. 103-108, 2016.

[54] Y. Liu, X. Ge, X. Dou et al., "Protein Inhibitor of Activated STAT 1 (PIAS1) protects against obesity-induced insulin resistance by inhibiting inflammation cascade in adipose tissue," Diabetes, vol. 64, no. 12, pp. 4061-4074, 2015.

[55] M. J. Alkhatatbeh, A. K. Enjeti, S. Acharya, R. F. Thorne, and L. F. Lincz, "The origin of circulating CD36 in type 2 diabetes," Nutrition \& Diabetes, vol. 3, article e59, 2013.

[56] S. Gautam, A. C. Gupta, and B. Monisha, "CD36 gene variants in early prediction of type 2 diabetes mellitus," Genetic Testing and Molecular Biomarkers, vol. 19, no. 3, pp. 144-149, 2015.

[57] P. Bozaykut, B. Karademir, B. Yazgan et al., "Effects of vitamin e on peroxisome proliferator-activated receptor $\gamma$ and nuclear factor-erythroid 2-related factor 2 in hypercholesterolemiainduced atherosclerosis," Free Radical Biology and Medicine, vol. 70, pp. 174-181, 2014.

[58] T. Kim and Q. Yang, "Peroxisome-proliferator-activated receptors regulate redox signaling in the cardiovascular system," World Journal of Cardiology, vol. 5, no. 6, pp. 164-174, 2013.
[59] K. M. Ali, A. Wonnerth, K. Huber, and J. Wojta, "Cardiovascular disease risk reduction by raising HDL cholesterolcurrent therapies and future opportunities," British Journal of Pharmacology, vol. 167, no. 6, pp. 1177-1194, 2012.

[60] M. Auclair, C. Vigouroux, F. Boccara et al., "Peroxisome proliferator-activated receptor- $\gamma$ mutations responsible for lipodystrophy with severe hypertension activate the cellular renin-angiotensin system," Arteriosclerosis, Thrombosis \& Vascular Biology, vol. 33, no. 4, pp. 829-838, 2013.

[61] H. He, H. Tao, H. Xiong et al., "Rosiglitazone causes cardiotoxicity via peroxisome proliferator-activated receptor \&independent mitochondrial oxidative stress in mouse hearts," Toxicological Sciences, vol. 138, no. 2, pp. 468-481, 2014.

[62] A. J. Scheen, N. Esser, and N. Paquot, "Antidiabetic agents: potential anti-inflammatory activity beyond glucose control," Diabetes \& Metabolism, vol. 41, no. 3, pp. 183-194, 2015.

[63] N. Esser, N. Paquot, and A. J. Scheen, "Anti-inflammatory agents to treat or prevent type 2 diabetes, metabolic syndrome and cardiovascular disease," Expert Opinion on Investigational Drugs, vol. 24, no. 3, pp. 283-307, 2015.

[64] E. Fuentes, L. Guzmán-Jofre, R. Moore-Carrasco, and I. Palomo, "Role of PPARs in inflammatory processes associated with metabolic syndrome (Review)," Molecular Medicine Reports, vol. 8, no. 6, pp. 1611-1616, 2013.

[65] H. E. Bays, "Adiposopathy: is 'sick fat' a cardiovascular disease?" Journal of the American College of Cardiology, vol. 57, no. 25, pp. 2461-2473, 2011.

[66] E. D. Abel, K. M. O’Shea, and R. Ramasamy, "Insulin resistance: metabolic mechanisms and consequences in the heart," Arteriosclerosis, Thrombosis \& Vascular Biology, vol. 32, no. 9, pp. 2068-2076, 2012.

[67] B. M. Y. Cheung and C. Li, "Diabetes and hypertension: is there a common metabolic pathway?" Current Atherosclerosis Reports, vol. 14, no. 2, pp. 160-166, 2012.

[68] U. J. Jung and M.-S. Choi, "Obesity and its metabolic complications: the role of adipokines and the relationship between obesity, inflammation, insulin resistance, dyslipidemia and nonalcoholic fatty liver disease," International Journal of Molecular Sciences, vol. 15, no. 4, pp. 6184-6223, 2014.

[69] J. V. Huang, C. R. Greyson, and G. G. Schwartz, "PPAR-\& as a therapeutic target in cardiovascular disease: evidence and uncertainty," Journal of Lipid Research, vol. 53, no. 9, pp. 1738$1754,2012$.

[70] T. H.-W. Huang and B. D. Roufogalis, "Healing the diabetic heart: modulation of cardiometabolic syndrome through peroxisome proliferator activated receptors (PPARs)," Current Molecular Pharmacology, vol. 5, no. 2, pp. 241-247, 2012.

[71] K. Drosatos, R. S. Khan, C. M. Trent et al., "Peroxisome proliferator-activated receptor- $\gamma$ activation prevents sepsisrelated cardiac dysfunction and mortality in mice," Circulation: Heart Failure, vol. 6, no. 3, pp. 550-562, 2013.

[72] P. Balakumar and N. Mahadevan, "Interplay between statins and PPARs in improving cardiovascular outcomes: a doubleedged sword?" British Journal of Pharmacology, vol. 165, no. 2, pp. 373-379, 2012.

[73] C. Giaginis, C. Klonaris, A. Katsargyris, G. Kouraklis, C. Spiliopoulou, and S. Theocharis, "Correlation of peroxisome proliferator-activated receptor $\gamma($ PPAR $-\gamma)$ and retinoid $\mathrm{x}$ receptor- $\alpha$ (RXR- $\alpha)$ expression with clinical risk factors in patients with advanced carotid atherosclerosis," Medical Science Monitor, vol. 17, no. 7, pp. CR381-CR391, 2011. 
[74] U. J. Jung, C. Torrejon, C. L. Chang, H. Hamai, T. S. Worgall, and R. J. Deckelbaum, "Fatty acids regulate endothelial lipase and inflammatory markers in macrophages and in mouse aorta: a role for PPAR $\gamma$," Arteriosclerosis, Thrombosis \& Vascular Biology, vol. 32, no. 12, pp. 2929-2937, 2012.

[75] M. Hulsmans, B. Geeraert, T. Arnould, C. Tsatsanis, and P. Holvoet, "PPAR agonist-induced reduction of Mcp1 in atherosclerotic plaques of obese, insulin-resistant mice depends on adiponectin-induced Irak3 expression," PLoS ONE, vol. 8, no. 4, Article ID e62253, 2013.

[76] Y. Huang, A. Di Lorenzo, W. Jiang, A. Cantalupo, W. C. Sessa, and F. J. Giordano, "Hypoxia-inducible factor- $1 \alpha$ in vascular smooth muscle regulates blood pressure homeostasis through a peroxisome proliferator-activated receptor- $\gamma$-angiotensin II receptor type 1 axis," Hypertension, vol. 62, no. 3, pp. 634-640, 2013.

[77] J. A. Beckman, F. Paneni, F. Cosentino, and M. A. Creager, "Diabetes and vascular disease: pathophysiology, clinical consequences, and medical therapy: part II," European Heart Journal, vol. 34, no. 31, pp. 2444-2456, 2013.

[78] C. V. Araújo, V. Estato, E. Tibiriçá, P. T. Bozza, H. C. CastroFaria-Neto, and A. R. Silva, "PPAR gamma activation protects the brain against microvascular dysfunction in sepsis," Microvascular Research, vol. 84, no. 2, pp. 218-221, 2012. 


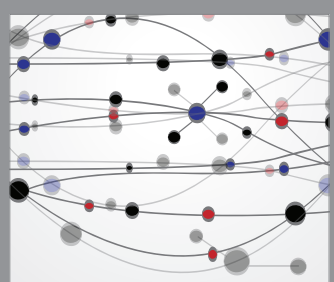

The Scientific World Journal
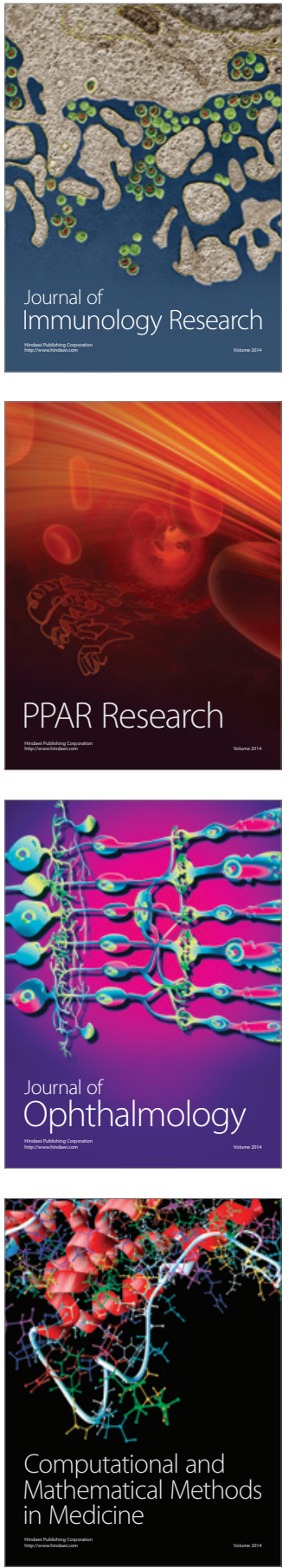

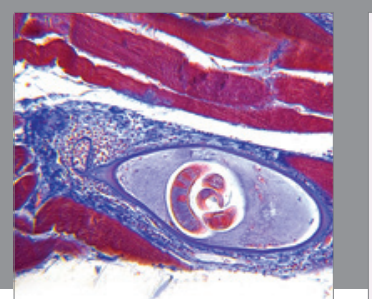

Gastroenterology Research and Practice

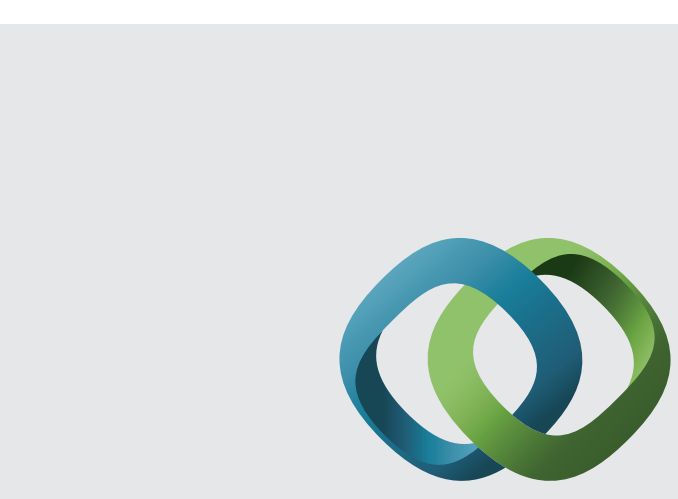

\section{Hindawi}

Submit your manuscripts at

http://www.hindawi.com
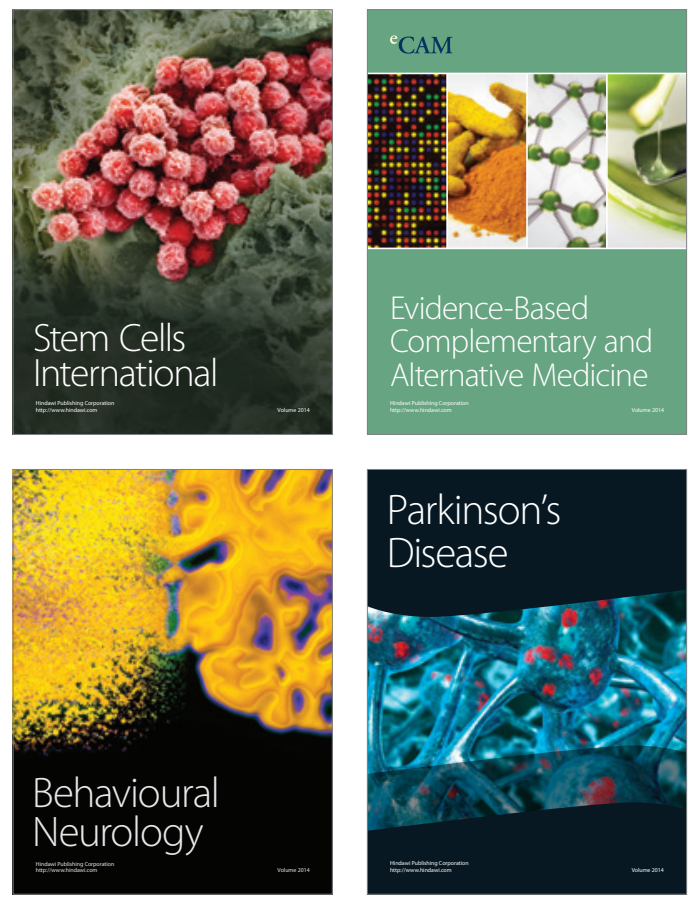
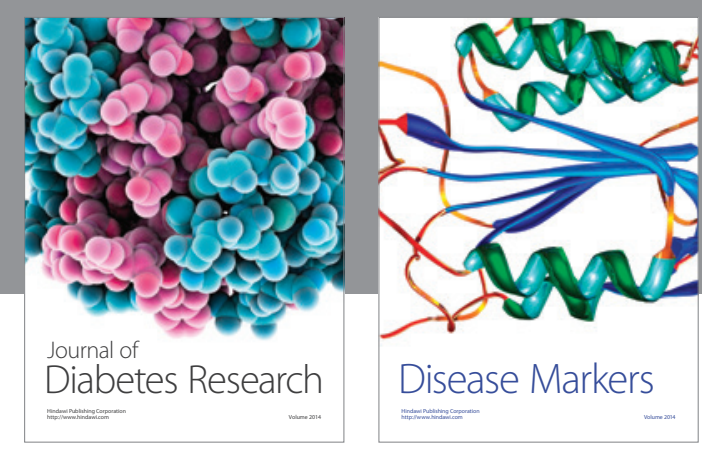

Disease Markers
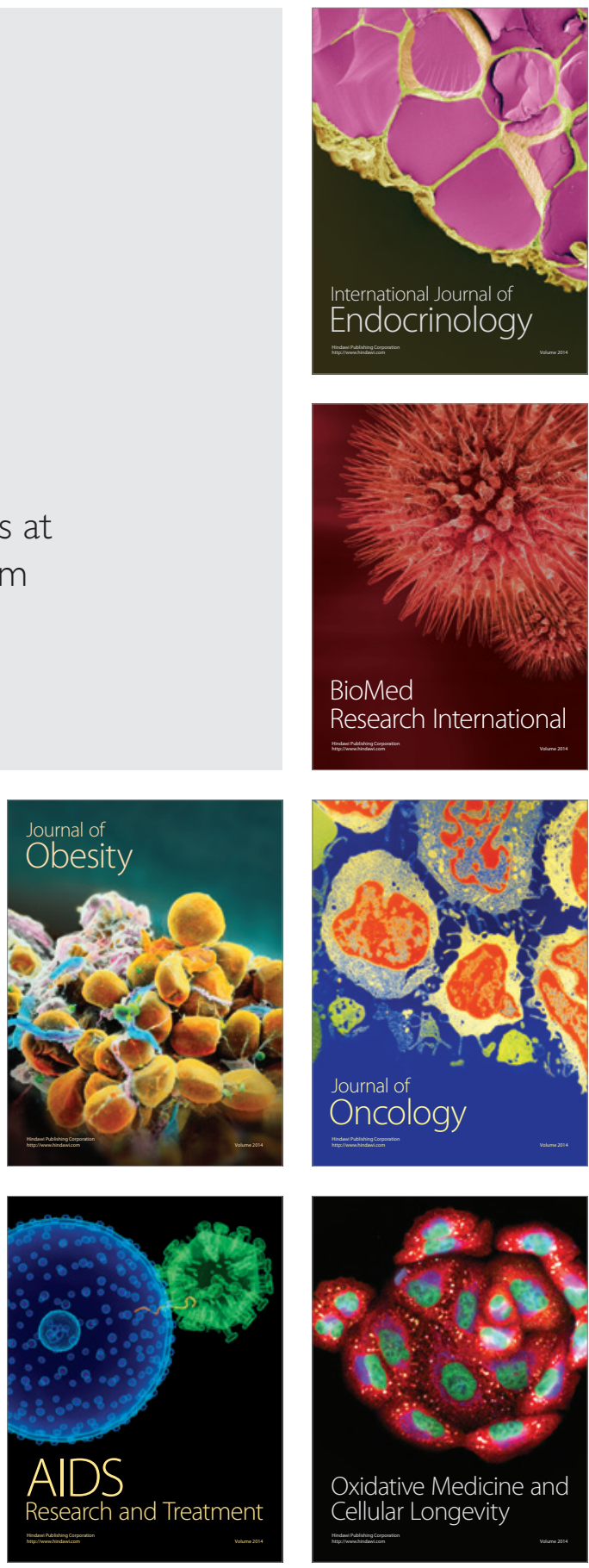